\title{
Migration Groups: A Poorly Explored Point of View for Genetic Damage Assessment Using Comet Assay in Human Lymphocytes
}

\author{
Mónica Reynoso-Silva ${ }^{1}$, Carlos Álvarez-Moya ${ }^{1, *}$, Rafael Ramírez-Velasco ${ }^{1}$, Alexis Gerardo Sámano-León ${ }^{1}$, \\ Erandi Arvizu-Hernández ${ }^{1}$, Hugo Castañeda-Vásquez ${ }^{2}$ and Mario Alberto Ruíz-Lopez ${ }^{3}$ \\ 1 Environmental Mutagenesis Laboratory, Cellular and Molecular Department, University of Guadalajara, \\ Jalisco C.P. 45200, Mexico; monica.reynoso@cucba.udg.mx (M.R.-S.); \\ rafael.rvelasco@alumnos.udg.mx (R.R.-V.); alexis.samano@alumnos.udg.mx (A.G.S.-L.); \\ erandi.arvizu@alumnos.udg.mx (E.A.-H.) \\ 2 Mastitis and Molecular Diagnostic, Internal Medicine Department, CUCBA University of Guadalajara, \\ Jalisco C.P. 45200, Mexico; hcastane@cucba.udg.mx \\ 3 Biotechnology Laboratory, Department of Botany and Zoology, University Centre for Biological and \\ Agricultural Sciences, Guadalajara University, Guadalajara, Jalisco C.P. 45200, Mexico; mruiz@cucba.udg.mx \\ * Correspondence: carlos.amoya@academicos.udg.mx; Tel.: +52-33-37771191
}

Citation: Reynoso-Silva, M.; Álvarez-Moya, C.; Ramírez-Velasco, R.; Sámano-León, A.G.; Arvizu-Hernández, E.; Castañeda-Vásquez, H.; Ruíz-Lopez, M.A. Migration Groups: A Poorly Explored Point of View for Genetic Damage Assessment Using Comet Assay in Human Lymphocytes. Appl. Sci. 2021, 11, 4094. https://doi.org/ 10.3390/app11094094

Academic Editors:

Marcos Fallanza Torices and Lucía Gómez-Coma

Received: 2 April 2021

Accepted: 26 April 2021

Published: 30 April 2021

Publisher's Note: MDPI stays neutral with regard to jurisdictional claims in published maps and institutional affiliations.

Copyright: (c) 2021 by the authors. Licensee MDPI, Basel, Switzerland. This article is an open access article distributed under the terms and conditions of the Creative Commons Attribution (CC BY) license (https:// creativecommons.org/licenses/by/ $4.0 /)$.
Featured Application: The proposed parameter here could help to improve the detection of genetic damage associated with certain genotoxic agents.

Abstract: A new point of view for genetic damage assessment using the comet assay is proposed based on the number of migration groups, the number of comets in each group, and the groups with the highest number of comets. Human lymphocytes were exposed to different concentrations of Methyl Methane Sulfonate (MMS), Maleic Hydrazide (MH), 2,4-Dichlorophenoxyacetic (2,4-D), and N-nitroso diethylamine (NDEA). Using comet assay, the migration means of the comets were determined and later grouped arbitrarily in migration groups with no higher differences than $1 \mu \mathrm{c}$. The number of migration groups, the number of comets in each group, and the groups with the highest number of comets (modes) were determined. All four of the genotoxic agents studied showed a significant increase $(p<0.05)$ in the tail length and the number of migration groups compared to the negative control. The number of migration groups did not show a significant variation between the four-genotoxic agents nor within their different concentrations. However, the comparison of the modes did show differences between the genotoxic agents, but not within the concentrations of a same genotoxic agent, which indicated a determined chemical interaction on the DNA. These parameters can improve the detection of genetic damage associated with certain genotoxic agents.

Keywords: comet assay; bioassays; DNA damage; human lymphocytes; genotoxicity; tail length groups

\section{Introduction}

During the past 30 years, the comet assay, also known as Single Cell Gel Electrophoresis (SCGE), has been used to assess DNA damage and its reparation in cells and tissues [1]. It is a rapid, sensible, and adjustable bioassay that detects genetic damage in individual cells with a wide range of applications [2-7]. Comet assay has been performed either in vitro or in vivo in a variety of species [8,9]. The major advantages of this assay include its relatively easy application to any tissue of interest and the detection of multiple types of DNA damage [10]. Comet assay measures the tail length of the comets. After electrophoresis, loops containing a break lose their supercoil so can move freely to anode, in this way the tail length indicates DNA broken [11]. Using another descriptors, the intensity of the tail regarding to the head indicates too the DNA breaks [12]. The magnitude of the tail length has a relationship with the level of DNA lesions in the cell [12]. Actually, some authors have reported certain variants in the protocol of the comet assay for detecting different 
types of specific genetic damage within the DNA, such as DNA single-strand breaks (SSB), alkali-labile sites (ALS), DNA-DNA/DNA-protein cross-linking, and SSB associated with incomplete excision repair sites [13-19]. Other variations of the test were developed by modifying it with enzymes for the detection of alkylated bases and the oxidation of purines and pyrimidines [11]. Despite its multiple modifications, this assay is still considered an unspecific technique [5,20].

Due to the great differences in tail migration among individual cells, the widely accepted criteria to determine genetic damage has been the use of migration averages of $25-100$ comets per individual $[15,19]$. This difference among the tail length is mainly given by the cell age [14], type of DNA damaged that occurred [21], and methodological variations of the assay, for instance, the low melting agarose percentage used, time of lysis, and electrophoresis [15], in addition to the differences within the observers [16] and statistical analysis used [17]. The large heterogeneity between the tail length of the comets observed in this test $[14,22,23]$ indicates different levels of DNA damage given by broken loops losing its supercoiling. Using the migration average criteria, the main property of this assay is to determine and differentiate genetic damage between cells or individual nuclei losing relevance. Different comet groups with a similar tail length (migration groups) have been observed [24-26]. Therefore, the grouping of cells with equal tail lengths could indicate DNA damage associated specifically with different ages, genotoxic agents, or diseases avoiding the loss of data generated by averaging.

In the present study, an analysis to characterize genetic damage caused by different agents using the alkaline comet assay based in three arbitrary parameters: number of migration groups, number of comets in each group, and the migration groups with the largest number of comets was proposed, with the aim of studying the differences in the genetic damage between individual cells and to extend the advantages of the use of the test in a wide variety of studies without increasing costs.

\section{Materials and Methods}

\subsection{Reagents Used}

Chemical mutagens and doses applied in this study were methyl methanesulfonate (MMS) (CAS 66-27-3) at 2.5, 5, and $10 \mathrm{mmol}(\mathrm{mM})$; maleic hidrazide (MH) (CAS 123-33-1n) at 5, 20, and $45 \mathrm{mM} ; 2,4$-dichlorophenoxyacetic acid (2,4-D) (CAS 94-75-7) at 0.5, 1, and $2 \mathrm{mM}$; N-nitroso diethylamine (NDEA) (CAS 62-75-9) at 5, 20, and $40 \mathrm{mM}$. They were all purchased from Sigma Chemical Co. (Guadalajara, Jalisco, México). Dimethyl sulfoxide (DMSO, CAS 67-68-5) and disodium EDTA (CAS 60-00-4) were provided by J.T. Baker (México City, México).

\subsection{Obtaining Blood Samples}

Human peripheral blood cells (HPBLs). Prior informed consent, nine drops of peripheral blood without anticoagulant were obtained by annular puncture of six students (three men and three women) not older than 20 years old, who had no history of smoking or drinking and that were never exposed to chemical substances or environmental contaminants. This information was obtained through the prior application of a questionnaire. HPBLs was immediately centrifuged at $200 \times \mathrm{g}$ for $10 \mathrm{~min}$ with three $\mathrm{mL}$ of phosphate buffer ( $160 \mathrm{mM} \mathrm{NaCl}, 8 \mathrm{mM} \mathrm{Na}_{2} \mathrm{HPO}_{4}, 4 \mathrm{mM} \mathrm{Na}_{2} \mathrm{HPO}_{4}, 50 \mathrm{mM}$ EDTA, $\mathrm{pH}$, and $4{ }^{\circ} \mathrm{C}$ ). The supernatant was removed, and the pellet was resuspended in $500 \mu \mathrm{L}$ of phosphate buffer (PBS) at $4{ }^{\circ} \mathrm{C}$ until its further use.

\subsection{Genetic Damage Induced by MMS, $M H, 2,4-D$ and NDEA}

Previously obtained samples containing the lymphocytes were mixed with $13 \mathrm{~mL}$ of PBS. The mixture was divided in 13 parts of $1 \mathrm{~mL}$. To induce genetic damage, each part was mixed with a mutagen $v / v$ during two hours and $4{ }^{\circ} \mathrm{C}$ and at the following final concentrations: (1) Negative control, (2) MMS $2.5 \mathrm{mM}$, (3) MMS 5 mM, (4) MMS 10 mM, (5) MH 5 mM, (6) MH 20 mM, (7) MH 45 mM, (8) 2,4-D 0.5 mM, (9) 2,4-D 1 mM, (10) 2,4-D 
$2 \mathrm{mM}$, (11) NDEA $5 \mathrm{mM}$, (12) NDEA $20 \mathrm{mM}$, (13) NDEA $40 \mathrm{mM}$. At the end of the treatment all the samples were washed 3 times with PBS, the pellet was then resuspended in $100 \mu \mathrm{L}$ of this same PBS to posteriorly be placed on the agarose gels. This procedure was performed twice for each sample of the six individuals.

\subsection{Alkaline Comet Assay}

The alkaline comet assay was carried out using the method of Speit and Hartmann [27]. Slides were covered with Normal Melting Point (NMP) agarose at 1\%, then the agarose was allowed to solidify, and then it was removed from the slides giving as a result a completely clean surface. Next, a $0.6 \%$ Low Melting Point (LMP) agarose layer was placed on each slide. Once it solidified, another agarose layer was added (10 $\mu \mathrm{L}$ of the suspension containing the whole blood and $90 \mu \mathrm{L}$ of the $0.5 \%$ LMP agarose). Finally, a third layer of $0.5 \%$ LMP agarose was added to cover the second layer. After that, the slides were immersed in lysis solution $\left(2.5 \mathrm{mM} \mathrm{NaCl}, 10 \mathrm{mM} \mathrm{Na}{ }_{2}\right.$ EDTA, $10 \mathrm{mM}$ Tris- $\mathrm{HCl}$, 1\% Sodium lauroyl sarcosinate, $1 \%$ Triton $\mathrm{X}-100$, and $10 \% \mathrm{DMSO}, \mathrm{pH} 10)$ for $2 \mathrm{~h}$ at $11^{\circ} \mathrm{C}$. After this, the slides were placed in a horizontal electrophoresis system with electrophoresis buffer (300 mM NaOH, $1 \mathrm{mM} \mathrm{Na} 2$ EDTA, pH 13) for $45 \mathrm{~min}$. The electrophoresis was then carried out for $30 \mathrm{~min}$ at $1.0 \mathrm{~V} / \mathrm{cm}$ with an amperage of $\sim 300 \mathrm{~mA}$ and at $10-15^{\circ} \mathrm{C}$. Thereafter, the slides were washed with distilled water and stained with $90 \mu \mathrm{L}$ of ethidium bromide $(100 \mu \mathrm{L}$ at $20 \mu \mathrm{g} / \mathrm{mL})$. Immediately after, the slides were immersed in distilled water for three minutes. Finally, the slides were rewashed with distilled water for $15 \mathrm{~min}$.

\subsection{Observation and Quantification of Comets}

A fluorescence microscope with an excitation filter of 515-560 nm was used for the quantification of the comets. The tail length was measured with the Comet assay system II software (ZEEIZ SINOPTIC MIKRO S.A DE C.V, México, 2012). Approximately 200 cometized cells per studied subject were analysed.

\subsection{Proposed Parameters}

The comet groups with about the same tail length are called Migration Groups (MG). In this study each MG differentiates one from another in $1 \mu \mathrm{c}$. Each MG represents a Characteristic Genetic Damage (CGD), the number of groups indicates the amount of Characteristic Genetic Damages (CGDs). The MG with the three largest numbers of comets represents the most frequent Characteristic Genetic Damage or modes.

\subsection{Statistical Analysis}

The statistical software Statplus 2 was used to perform an analysis of variance (ANOVA), a Fisher test, and an F-Test for variances of two samples. A confidence level of 0.05 was used.

The most recent recommendations reported were taken into account to describe the procedures and results using the comet test [27].

\section{Results}

The data obtained from the test after the exposure of the lymphocytes to different concentrations of MMS, MH, NDEA, and 2,4-D were arbitrarily organized in MG with differences of $1 \mu \mathrm{c}$ (Figure 1A-D). 

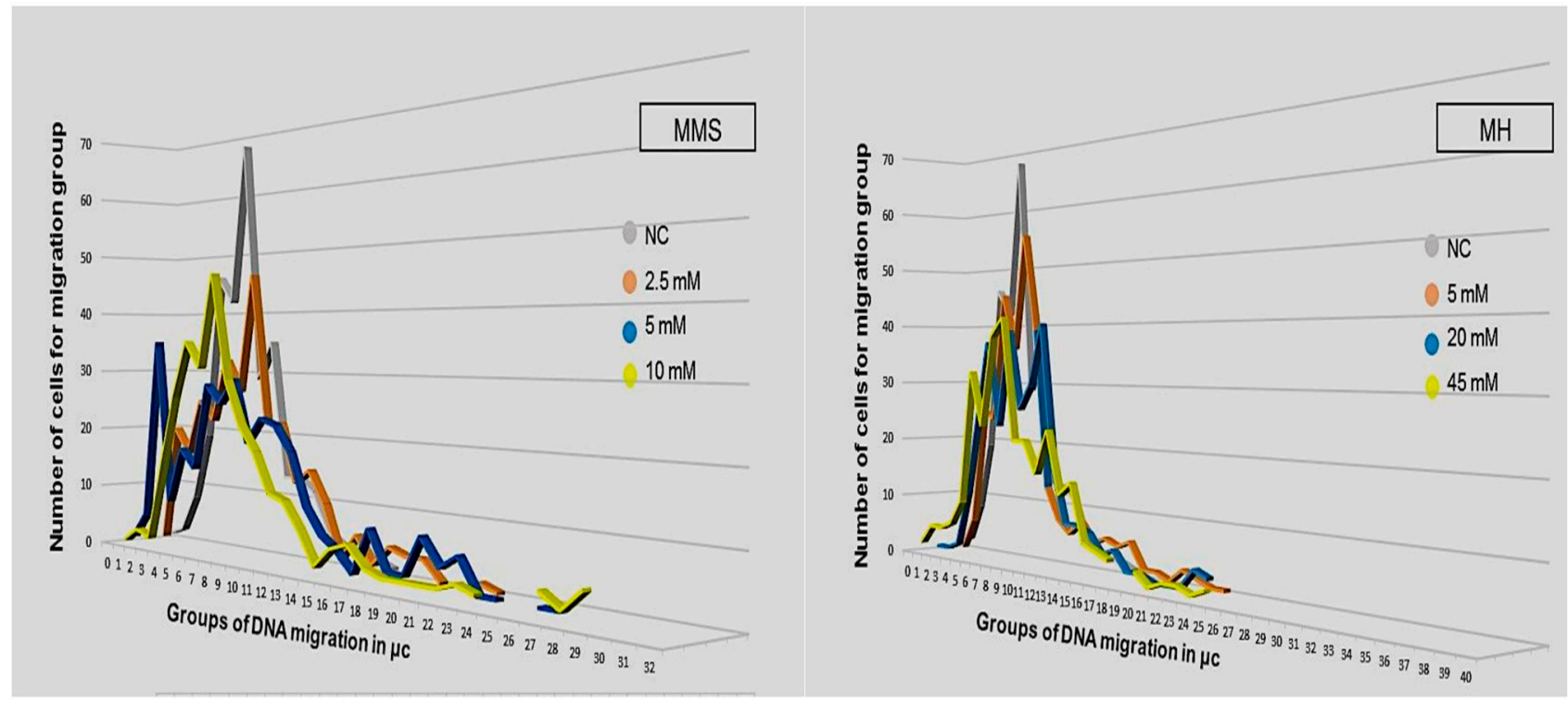

C
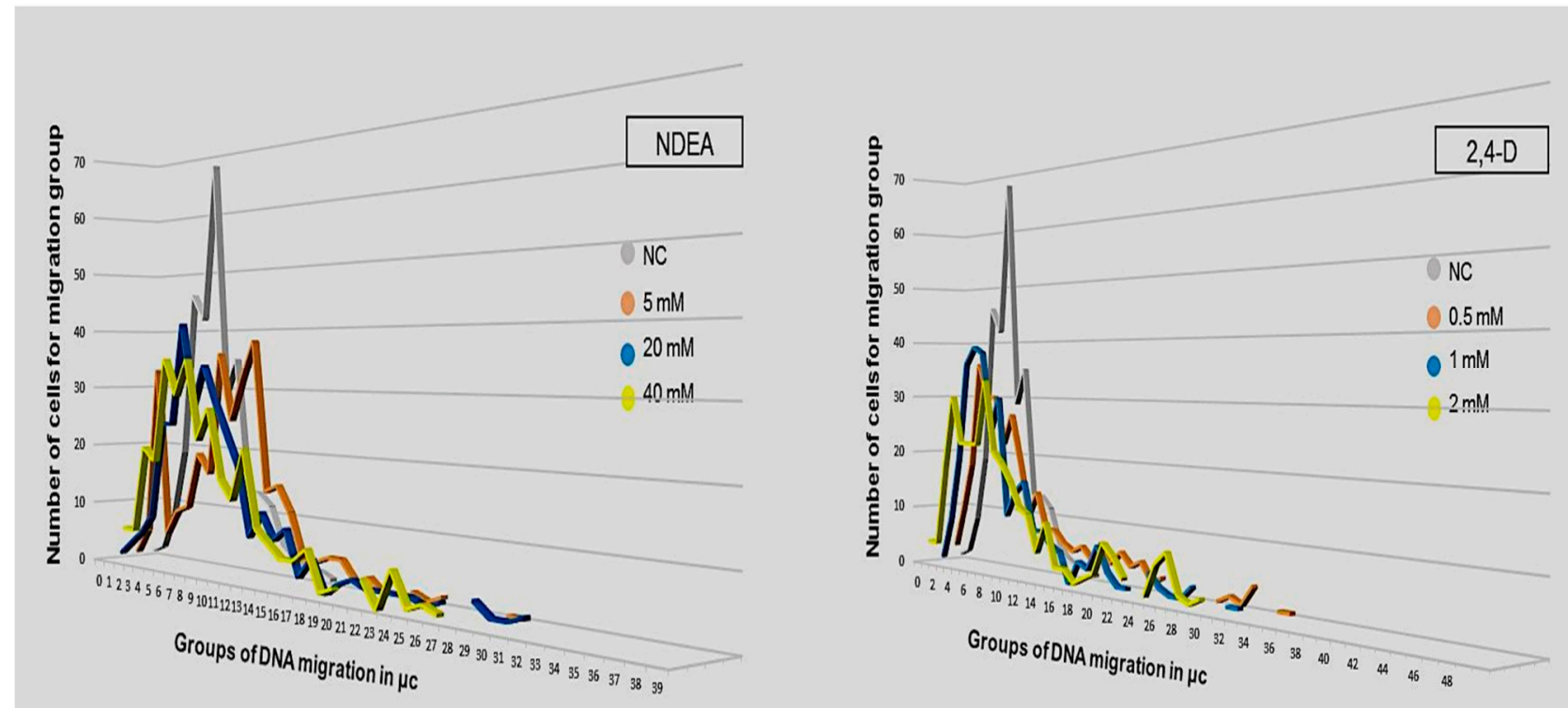

Figure 1. Migration groups and number of comets observed per group after exposure to three different concentrations of MMS (A), MH (B), NDEA (C), and 2,4-D (D). Each peak corresponds to a migration group with a different number of comets.

In each case, the negative control (Figure 2, Table 1) always showed a significant lower number of MG $(p<0.05)$. On the contrary, MMS, MH, 2,4-D, and NDEA induced the largest number of groups in proportion to the concentration (Figure 2). The comparison between the number of MG and the genotoxic agents and their different concentrations did not show significant differences $(p>0.05)$. However, modes were different among the genotoxic agents but not within the concentrations of a same genotoxic (Table 1). 


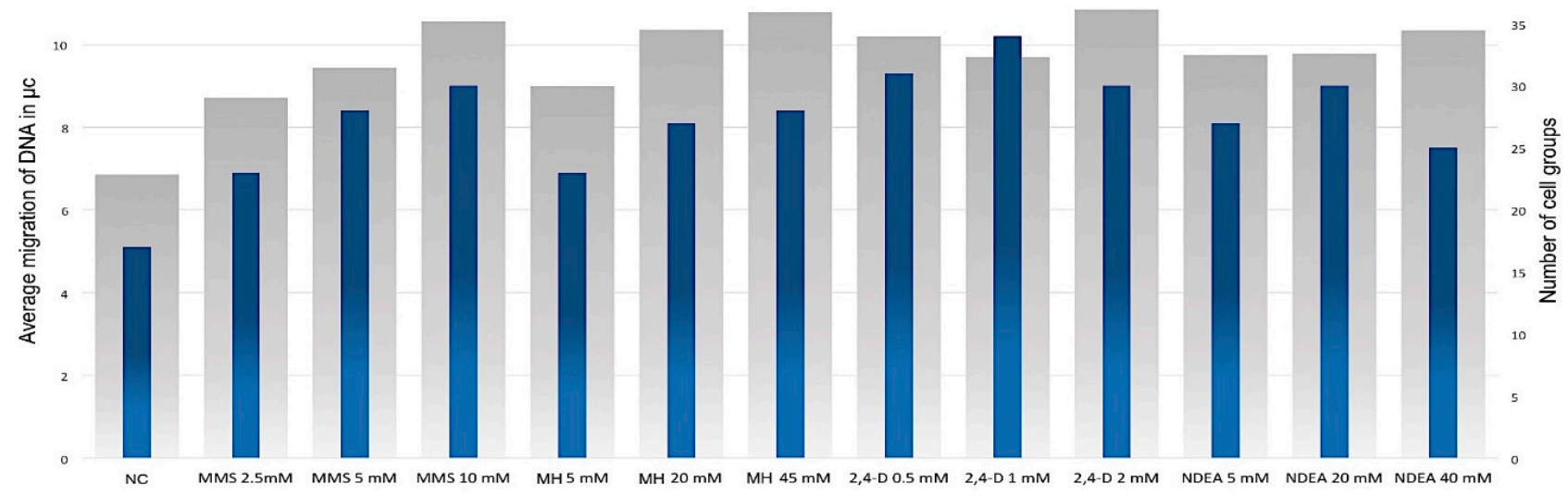

Lymphocytes exposed to different concentrations of MMS, MH, 2,4-D and NDEA

"Average migration anumber of groups

Figure 2. Average migration of DNA and number of migration groups observed in lymphocytes exposed to different concentrations of MMS, MH, 2,4-D, and NDEA. On the left, the average DNA migration is shown, and on the right side, the number of cells in each (comets) are indicated.

Table 1. Migration groups and number of comets generated in each one caused by the exposure to MMS, MH, 2,4-D, and NDEA. The groups with the three largest numbers of comets (modes) are indicated in grey $>$ blue $>$ orange.

\begin{tabular}{|c|c|c|c|c|c|c|c|c|c|c|c|c|c|}
\hline \multirow[b]{2}{*}{$\begin{array}{l}\text { Migration } \\
\text { Groups } \\
\text { in } \mu \mathrm{c}\end{array}$} & \multicolumn{13}{|c|}{ Experimental Groups } \\
\hline & NC & $\begin{array}{c}\text { MMS } \\
2.5 \mathrm{mM}\end{array}$ & $\begin{array}{l}\text { MMS } \\
5 \mathrm{mM}\end{array}$ & $\begin{array}{c}\text { MMS } \\
10 \mathrm{mM}\end{array}$ & $\begin{array}{c}\text { MH } \\
5 \mathrm{mM}\end{array}$ & $\begin{array}{c}\text { MH } \\
20 \mathrm{mM}\end{array}$ & $\begin{array}{c}\text { MH } \\
45 \mathrm{mM}\end{array}$ & $\begin{array}{c}2,4-\mathrm{D} \\
0.5 \mathrm{mM}\end{array}$ & $\begin{array}{c}2,4-\mathrm{D} \\
1 \mathrm{mM}\end{array}$ & $\begin{array}{l}2,4-\mathrm{D} \\
2 \mathrm{mM}\end{array}$ & $\begin{array}{c}\text { NDEA } \\
5 \mathrm{mM}\end{array}$ & $\begin{array}{l}\text { NDEA } \\
20 \mathrm{mM}\end{array}$ & $\begin{array}{l}\text { NDEA } \\
40 \mathrm{mM}\end{array}$ \\
\hline 0 & 1 & & 1 & & & & & & & & 1 & 1 & \\
\hline 1 & 2 & 1 & 5 & 1 & & 1 & 2 & 3 & 1 & 4 & 5 & 3 & \\
\hline 2 & 8 & 20 & 35 & 3 & 1 & 1 & 5 & 10 & 8 & 4 & 33 & 5 & 6 \\
\hline 3 & 19 & 16 & 8 & 2 & 6 & 2 & 5 & 18 & 19 & 18 & 5 & 8 & 6 \\
\hline 4 & 46 & 25 & 17 & 14 & 25 & 11 & 6 & 36 & 36 & 30 & 9 & 24 & 20 \\
\hline 5 & 42 & 22 & 14 & 26 & 24 & 24 & 10 & 30 & 39 & 22 & 10 & 24 & 18 \\
\hline 6 & 68 & 32 & 28 & 35 & 45 & 37 & 32 & 30 & 38 & 22 & 19 & 41 & 35 \\
\hline 7 & 29 & 27 & 25 & 31 & 36 & 23 & 23 & 22 & 24 & 22 & 16 & 27 & 29 \\
\hline 8 & 35 & 46 & 29 & 46 & 55 & 39 & 38 & 27 & 30 & 33 & 36 & 34 & 35 \\
\hline 9 & 13 & 22 & 19 & 29 & 39 & 26 & 41 & 19 & 10 & 21 & 25 & 28 & 22 \\
\hline 10 & 13 & 22 & 23 & 22 & 13 & 30 & 21 & 10 & 14 & 19 & 32 & 23 & 27 \\
\hline 11 & 11 & 13 & 22 & 18 & 8 & 40 & 21 & 14 & 16 & 16 & 38 & 18 & 16 \\
\hline 12 & 5 & 15 & 18 & 12 & 6 & 17 & 16 & 8 & 8 & 12 & 14 & 7 & 13 \\
\hline 13 & 3 & 10 & 10 & 11 & 8 & 8 & 23 & 8 & 8 & 11 & 15 & 11 & 21 \\
\hline 14 & 2 & 2 & 6 & 7 & 5 & 8 & 13 & 6 & 6 & 5 & 11 & 7 & 9 \\
\hline 15 & 2 & 6 & 4 & 2 & 6 & 7 & 15 & 5 & 5 & 10 & 4 & 9 & 7 \\
\hline 16 & 1 & 2 & 1 & 5 & 5 & 4 & 6 & 6 & & 3 & 4 & 2 & 5 \\
\hline 17 & & 5 & 8 & 6 & 6 & 5 & 5 & 4 & 4 & 3 & 5 & 5 & 5 \\
\hline 18 & & 4 & 2 & 3 & 2 & 2 & 4 & 7 & 3 & 1 & 5 & & 7 \\
\hline 19 & & 4 & 2 & 2 & 2 & 2 & & 4 & 7 & 2 & 2 & 2 & 1 \\
\hline 20 & & 1 & 8 & 2 & 1 & 1 & 3 & 6 & 3 & 3 & 3 & 3 & 2 \\
\hline 21 & & & 4 & 2 & 3 & 1 & 1 & 4 & 1 & 8 & 1 & 2 & \\
\hline 22 & & 2 & 6 & 2 & 2 & 1 & 2 & 5 & 1 & 6 & & 2 & 4 \\
\hline 23 & & 1 & 1 & 3 & 1 & 4 & 2 & 2 & & 3 & 2 & 2 & \\
\hline 24 & & & 1 & 2 & 1 & 3 & 1 & 3 & 4 & & 1 & 2 & 6 \\
\hline 25 & & 2 & & & & & 2 & & 2 & 1 & 2 & 1 & 1 \\
\hline 26 & & & 1 & & & 1 & & 3 & 1 & 6 & & 2 & 2 \\
\hline
\end{tabular}


Table 1. Cont.

\begin{tabular}{|c|c|c|c|c|c|c|c|c|c|c|c|c|c|}
\hline \multirow[b]{2}{*}{$\begin{array}{l}\text { Migration } \\
\text { Groups } \\
\text { in } \mu \mathrm{c}\end{array}$} & \multicolumn{13}{|c|}{ Experimental Groups } \\
\hline & NC & $\begin{array}{c}\text { MMS } \\
2.5 \mathrm{mM}\end{array}$ & $\begin{array}{l}\text { MMS } \\
5 \mathrm{mM}\end{array}$ & $\begin{array}{c}\text { MMS } \\
10 \mathrm{mM}\end{array}$ & $\begin{array}{c}\text { MH } \\
5 \mathrm{mM}\end{array}$ & $\begin{array}{c}\text { MH } \\
20 \mathrm{mM}\end{array}$ & $\begin{array}{c}\mathrm{MH} \\
45 \mathrm{mM}\end{array}$ & $\begin{array}{c}2,4-\mathrm{D} \\
0.5 \mathrm{mM}\end{array}$ & $\begin{array}{l}2,4-\mathrm{D} \\
1 \mathrm{mM}\end{array}$ & $\begin{array}{l}2,4-\mathrm{D} \\
2 \mathrm{mM}\end{array}$ & $\begin{array}{c}\text { NDEA } \\
5 \mathrm{mM}\end{array}$ & $\begin{array}{l}\text { NDEA } \\
20 \mathrm{mM}\end{array}$ & $\begin{array}{l}\text { NDEA } \\
40 \mathrm{mM}\end{array}$ \\
\hline 27 & & & 1 & 4 & & & 1 & & 1 & 8 & & & 1 \\
\hline 28 & & & & 2 & & & & & 3 & 2 & & 3 & \\
\hline 29 & & & 1 & 5 & & & & 1 & & 1 & 1 & 1 & 1 \\
\hline 30 & & & & & & & & 2 & & 2 & 1 & 1 & \\
\hline 31 & & & & 1 & & & & 1 & 1 & & & 2 & \\
\hline 32 & & & & & & & & 4 & 1 & 2 & & & \\
\hline 33 & & & & 2 & & & & & & & & & \\
\hline 34 & & & & & & 1 & & 1 & & & & & 1 \\
\hline 35 & & & & & & & & 1 & 2 & & & & \\
\hline 36 & & & & & & & 1 & & & & & & \\
\hline 37 & & & & & & & & & & & & & \\
\hline 38 & & & & & & & 1 & & 1 & & & & \\
\hline 39 & & & & & & & & & & & & & \\
\hline 40 & & & & & & & & & & & & & \\
\hline 41 & & & & & & 1 & & & 1 & & & & \\
\hline 42 & & & & & & & & & & & & & \\
\hline 43 & & & & & & & & & & & & & \\
\hline 44 & & & & & & & & & & & & & \\
\hline 45 & & & & & & & & & & & & & \\
\hline 46 & & & & & & & & & 1 & & & & \\
\hline 47 & & & & & & & & & & & & & \\
\hline 48 & & & & & & & & & & & & & \\
\hline 49 & & & & & & & & & 1 & & & & \\
\hline
\end{tabular}

Methyl Methane Sulfonate (MMS), Maleic Hydrazide (MH), 2,4-Dichlorophenoxyacetic (2,4-D), N-nitroso diethylamineNDEA.

A clear relation between the average genetic damage, the total number of migration groups, and the concentration was observed for MMS and MH (Figure 1A,B). However, no relation was observed for 2,4-D and NDEA (Figure 1C,D). All MG and number of comets generated after exposure to MMS, MH, 2,4-D, and NDEA are shown in Table 1. Each migration group represents a CGD. The groups with the highest number of comets (modes) are highlighted in color. The negative control always showed the lowest number of MG with 16 , and modes of 6,4 , and $5 \mu \mathrm{c}$. Regardless of their concentration, MMS and MH showed modes of 6,7 , and $8 \mu \mathrm{c}$. 2,4-D showed modes of 4, 5, 6, and even $8 \mu \mathrm{c}$. NDEA generated modes of $2,8,11,6,8,9$, and $6,7,8$ for the concentrations of 5, 20, and $40 \mathrm{mM}$, respectively.

\section{Discussion}

The alkaline comet assay can be used to study genotoxicity and genetic damage [15]. It is based on the measurement of the tail length of the comet and the measurement of migrated DNA percentage [13]. Even though multiple adaptations have been made to this assay in order to detect specific genetic damage, it is still considered as a test that only detects unspecific genetic damage $[5,20]$ characterized by a high heterogeneity among the observed comets $[24,26,28]$. In this study, we used the tail length descriptor because despite of being the simplest criteria and it is possible to observe great heterogeneity in the magnitude of the migration of comets which allows cells with similar tail length size to be grouped.

In an attempt to make the comet test more specific for the detection of genetic damage, human lymphocytes were exposed to MMS, MH, 2,4-D, and NDEA in different concentrations and an increase in genetic damage was observed, depending on the genotoxic agent and the concentration, which allowed organizing the data arbitrarily in migration groups of $1 \mu \mathrm{c}$. Thus, differences between single comets (differences in genetic damage) are framed in a MG so that way, they do not lose relevance as a consequence of the "average" effect, which allows us to determine and differentiate genetic damage between individual comets. 
Each migration group indicates what we call a CGD, the number of MG represent distinct CGDs and the three MG with the largest number of comets represent the most frequent CGD (modes). Some of the groups showed the largest number of comets indicating that these types of damage are the ones that occur more frequently, and each of them depend on the genotoxic agent as it was shown in Table 1 where the most frequent CGD in the negative control corresponds to the $6>4>5 \mu \mathrm{c}$ groups.

Regardless of the concentration, the CGD for MMS and MH was at 6, 7, and $8 \mu \mathrm{c}$. Other CGD: 4, 5, 6, and $7 \mu \mathrm{c}$ were observed for 2,4-D and 5, 6, 7, and $8 \mu \mathrm{c}$ for NDEA.

Nuclei can be classified as damaged or undamaged according to the percentile of the length of the tail [29]. However, the GM can be used as an additional indicator of genetic damage. Although previous reports have shown comet groups with different degree of damage $[24,26,30]$, far too little attention has been paid to the role of migration groups in the comet assay. In this study, MG were formed. Each group was different from one another for $1 \mu \mathrm{c}$, therefore, observing CGD, could be a method that broadens the sensibility of the comet assay but still without being considered a method that detects specific genetic damage.

Alkylating agents MMS and NDEA cause mutational events on the DNA [31] that may be related with the increase of migration groups and a higher frequency of some of them, which consequently indicates that these genotoxic agents induce certain CGD more frequently. A similar situation may occur for 2,4-D and MH. However, the genotoxic mechanism of action of these agents is still not clear [32]. The comet assay can detect DNA changes induced by these genotoxic agents, yet it detects the changes without determining the molecular mechanism. This is the reason why it is considered as a test that detects unspecific genetic damage [5,20].

Despite the non-specificity of the comet assay, it generates a certain number of MG directly proportional to the genetic damage and the genotoxic agent concentration. 2,4-D and NDEA also generated MG. Nevertheless, they were not related with the genotoxic agent concentration. This behavior is due to the fact that the highest concentrations tend to cause high level of DNA fragmentation resulting in comets of great magnitude, which cannot be visualized in their totality by the image analyzer. As a result, comets of equal or shorter magnitude than at lower concentrations are observed. This behavior has previously been reported in NDEA [33].

As it was expected, the negative control showed the lowest total number of MG, which indicated cells with a different level of damage probably associated to the cell age [14] and the type of damage caused on the DNA [21].

\section{Conclusions}

The GMs are proposed as a descriptor of genetic damage based on (a) the grouping of comets with size similar of tail length, (b) the quantification of the number of comets in each group, and (c) the GM with the highest number of comets. These characteristics could help to associate a genotoxic agent to a distinctive genetic damage change. It is worth mentioning that this procedure does not require an additional cost or special equipment, only the analysis of statistical data. It could also be used to detect CGD associated to diseases characterized by genome instability [34], cellular aging studies, and in studies related to environmental contamination by genotoxic agents [16].

Author Contributions: C.Á.-M. and M.R.-S. carried out the experimental works and manuscript preparation; R.R.-V. and A.G.S.-L. conducted the studies with comet assay; E.A.-H. and H.C.-V. participated in the experimental phases and in the preparation and revision of the manuscript; M.A.R.-L. was responsible for the revision of the figures and tables and general review of the manuscript. The authors approved the final manuscript. All authors have read and agreed to the published version of the manuscript.

Funding: This study received the support of the National Council of Science and Technology, Conacyt, and the Ministry of Public Education (SEP), through a scholarship for doctoral studies in Biosystematic, Ecology, and Management of Natural and Agricultural Resources (Bemarena). 
Institutional Review Board Statement: The Institutional ethical committee for treatment of animals approved all protocols followed in this study (CUCBA). The study was conducted according to the guidelines of the Declaration of Helsinki, and approved by the Coordinación de investigación (CUCBA, DBCM 2018).

Informed Consent Statement: Written informed consent was obtained from all subjects involved in the study.

Data Availability Statement: The data presented in this study are available on request from the corresponding author.

Acknowledgments: All authors appreciate the support given by the Guadalajara University.

Conflicts of Interest: The authors declare that there is no conflict of interest that could be perceived as prejudicial to the impartiality of the reported research.

\section{References}

1. Møller, P. The comet assay: Ready for 30 more years. Mutagenesis 2018, 33, 1-7. [CrossRef] [PubMed]

2. Cortés-Gutiérrez, E.I.; Dávila-Rodríguez, M.I.; Fernández, J.L.; López-Fernández, C.; Gosálbez, A.; Gosálvez, J. New application of the comet assay: Chromosome-comet assay. J. Histochem. Cytochem. 2011, 59, 655-660. [CrossRef] [PubMed]

3. Martus, H.J.; Hayashi, M.; Honma, M.; Kasper, P.; Gollapudi, B.; Mueller, L.; Schoeny, R.; Uno, Y.; Kirkland, D.J. Summary of major conclusions from the 6th international workshop on genotoxicity testing (IWGT), Foz do Iguaçu, Brazil. Mutat. Res. Genet. Toxicol. Environ. Mutagen. 2015, 783, 1-5. [CrossRef] [PubMed]

4. Fahim, M.; Ahmed, A.; Hussain, S. Single Cell Gel Electrophoresis and its Applications in Different Fields. J. Bioequiv. Availab. 2017, 1, 1-4.

5. Rodríguez, R.A.; Noris, G.E.; Fundora, T.M.T. Principios y relevancia del ensayo cometa. Rev. Cubana Investig. Bioméd. 2016, 35, 184-194.

6. Singh, N.P.; McCoy, M.T.; Tice, R.R.; Schneider, E.L. A simple technique for quantitation of low levels of DNA damage in individual cells. Exp. Cell Res. 1988, 175, 184-191. [CrossRef]

7. Alvarez-Moya, C.; Santerre-Lucas, A.; Zúñiga-González, G.; Torres-Bugarín, O.; Padilla-Camberos, E.; Feria-Velasco, A. Evaluation of genotoxic activity of maleic hydrazide, ethyl methane sulfonate, and N-nitroso diethylamine in Tradescantia. Salud Publ. Mex. 2001, 43, 563-569. [CrossRef]

8. Olive, P.L.; Banáth, J.P. The comet assay: A method to measure DNA damage in individual cells. Nat. Protoc. 2006, 1, 23-29. [CrossRef]

9. Gajski, G.; Žegura, B.; Ladeira, C.; Novak, M.; Sramkova, M.; Pourrut, B.; Collins, A. The comet assay in animal models: From bugs to whales-(Part 2 Vertebrates). Mutat. Res./Rev. Mutat. Res. 2019, 781, 130-164. [CrossRef]

10. Koppen, G.; Toncelli, L.M.; Triest, L.; Verschaeve, L. The comet assay: A tool to study alteration of DNA integrity in developing plant leaves. Mech. Ageing Dev. 1999, 110, 13-24. [CrossRef]

11. Azqueta, A.; Collins, A.R. The essential comet assay: A comprehensive guide to measuring DNA damage and repair. Arch. Toxicol. 2013, 87, 949-968. [CrossRef] [PubMed]

12. Møller, P.; Loft, S.; Ersson, C.; Koppen, G.; Dusinska, M.; Collins, A. On the search for an intelligible comet assay descriptor. Front. Genet. 2014, 5, 217. [PubMed]

13. Collins, A.R.; Oscoz, A.A.; Brunborg, G.; Gaivão, I.; Giovannelli, L.; Kruszewski, M.; Smith, C.C.; Štětina, R. The comet assay: Topical issues. Mutagenesis 2008, 23, 143-151. [CrossRef]

14. Forchhammer, L.; Bräuner, E.V.; Folkmann, J.K.; Danielsen, P.H.; Nielsen, C.; Jensen, A.; Loft, S.; Friis, G.; Møller, P. Variation in assessment of oxidatively damaged DNA in mononuclear blood cells by the comet assay with visual scoring. Mutagenesis 2008, 23, 223-231. [CrossRef]

15. Tice, R.R.; Agurell, E.; Anderson, D.; Burlinson, B.; Hartmann, A. Single cell gel/comet assay: Guidelines for in vitro and in vivo genetic toxicology testing. Environ. Mol. Mutagen. 2000, 35, 206-221. [CrossRef]

16. Jha, A.N. Ecotoxicological applications and significance of the comet assay. Mutagenesis 2008, 23, 207-221. [CrossRef] [PubMed]

17. Speit, G.; Kojima, H.; Burlinson, B.; Collins, A.R.; Kasper, P. Critical issues with the in vivo comet assay: A report of the comet assay working group in the 6th International Workshop on Genotoxicity Testing (IWGT). Mutat. Res. Genet. Toxicol. Environ. Mutagen. 2015, 783, 6-12. [CrossRef]

18. Collins, A.R. The Use of Bacterial Repair Endonucleases in the Comet Assay. Methods Mol. Biol. 2011, 691, 137-147. [PubMed]

19. Olive, P.L.; Banath, J.P. Detection of DNA double-strand breaks through the cell cycle after exposure to X-rays, bleomycin, etoposide and ${ }^{125}$ IdUrd. Int. J. Radiat. Biol. 1993, 64, 349-358. [CrossRef] [PubMed]

20. Alvarez-Moya, C.; Reynoso-Silva, M.; Canales-Aguirre, A.A.; Chavez-Chavez, J.O.; Castañeda-Vázquez, H.; Feria-Velasco, A.I. Heterogeneity of genetic damage in cervical nuclei and lymphocytes in women with different levels of dysplasia and cancerassociated risk factors. BioMed Res. Int. 2015, 2015, 293408. [CrossRef] [PubMed]

21. Lovell, D.P.; Omori, T. Statistical issues in the use of the comet assay. Mutagenesis 2008, 23, 171-182. [CrossRef] [PubMed] 
22. Miyaji, C.K.; Jordão, B.Q.; Ribeiro, L.R.; Eira, A.F.; Cólus, I.M. Genotoxicity and antigenotoxicity assessment of shiitake (Lentinula edodes (Berkley) Pegler) using the Comet assay. Genet. Mol. Biol. 2004, 27, 108-114. [CrossRef]

23. Nuñes, A.P.; Ferreira-Machado, S.C.; Nunes, R.M.; Dantas, F.J.; De Mattos, J.C. Analysis of genotoxic potentiality of stevioside by comet assay. Food Chem. Toxicol. 2007, 45, 662-666. [CrossRef]

24. Friedberg, E.C.; Walker, G.C.; Siede, W.; Wood, R.D. DNA Repair and Mutagenesis; American Society for Microbiology Press: Whashington, DC, USA, 2005; pp. 71-98.

25. Fedel-Miyasato, L.; Formagio, A.; Auharek, S.; Kassuya, C.; Navarro, S.; Cunha-Laura, A.; Monreal, A.; Vieira, M.; Oliveira, R. Antigenotoxic and antimutagenic effects of Schinus terebinthifolius Raddi in Allium cepa and Swiss mice: A comparative study. Genet. Mol. Res. 2014, 13, 3411-3425. [CrossRef] [PubMed]

26. Lee, E.; Oh, E.; Sul, D.; Lee, J. Use of the tail moment of the lymphocytes to evaluate DNA damage in human biomonitoring studies. Toxicol. Sci. 2004, 81, 121-132. [CrossRef]

27. Møller, P.; Azqueta, A.; Boutet-Robinet, E.; Koppen, G.; Bonassi, S.; Milić, M.; Gajski, G.; Costa, S.; Teixeira, J.P.; Pereira, C.C.; et al. Minimum Information for Reporting on the Comet Assay (MIRCA): Recommendations for describing comet assay procedures and results. Nat. Protoc. 2020, 15, 3817-3826. [CrossRef]

28. Mauro, M.O.; Monreal, M.T.; Silva, M.; Pesarini, J.R.; Mantovani, M.S. Evaluation of the antimutagenic and anticarcinogenic effects of inulin in vivo. Genet. Mol. Res. 2013, 12, 2281-2293. [CrossRef] [PubMed]

29. Gerić, M.; Gajski, G.; Oreščanin, V.; Garaj-Vrhovac, V. Seasonal variations as predictive factors of the comet assay parameters: A retrospective study. Mutagenesis 2018, 33, 53-60. [CrossRef] [PubMed]

30. Andem, A.B.; Agbor, R.B.; Ekpo, I.A. Review on Comet Assay: A reliable tool for assessing DNA damage in animal models. J. Curr. Res. 2013, 1, 405-427.

31. Dhawan, A.; Bajpayee, M.; Parmar, D. Comet assay: A reliable tool for the assessment of DNA damage in different models. Cell Biol. Toxicol. 2009, 25, 5-32. [CrossRef]

32. Ateeq, B.; Farah, M.A.; Ahmad, W. Detection of DNA damage by alkaline single cell gel electrophoresis in 2, 4-dichlorophenoxyaceticacid-and butachlor-exposed erythrocytes of Clarias batrachus. Ecotoxicol. Environ. Saf. 2015, 62, 348-354. [CrossRef]

33. Alvarez-Moya, C.; Reynoso Silva, M.; Villalobos Arámbula, A.R.; Islas Sandoval, A.; Castañeda Vasquez, H.; González Montes, R.M. Evaluation of genetic damage induced by glyphosate isopropylamine salt using Tradescantia bioassays. Genet. Mol. Biol. 2011, 34, 127-130. [CrossRef] [PubMed]

34. Mihaljevic, O.; Zivancevic-Simonovic, S.; Milosevic-Djordjevic, O.; Djurdjevic, P.; Jovanovic, D.; Todorovic, Z.; Grujicic, D.; Radovic-Jakovljevic, M.; Tubic, J.; Markovic, A.; et al. Apoptosis and genome instability in children with autoimmune diseases. Mutagenesis 2018, 33, 351-357. [CrossRef] [PubMed] 